\title{
Peranan Pupuk Nitrogen dan Fosfor pada Tanaman Kelapa Sawit (Elaeis guineensis Jacq.) Belum Menghasilkan Umur Tiga Tahun
}

\section{Role of Nitrogen and Phosphorus Fertilizer on Oil Palm (Elaeis guineensis Jacq.) Three Years Old Immature Tree}

\author{
Jabal Albari, Supijatno", dan Sudradjat
}

Departemen Agronomi dan Hortikultura, Fakultas Pertanian, Institut Pertanian Bogor (Bogor Agricultural University), Jl. Meranti, Kampus IPB Darmaga, Bogor 16680, Indonesia Telp. \& Faks.62-251-8629353 e-mail agronipb@indo.net.id

*Penulis Korespondensi : supijatno@yahoo.co.id

Disetujui : 15 Januari 2018 / Published Online 23 Januari 2018

\begin{abstract}
The land will be limited to extending oil palm plantations now, so required increasing productivity by improving the effectiveness and efficiency of fertilization. The purpose of this research was to study the vegetative growth and production of young plants to produce fresh fruit bunches of oil palm on $N$ and $P$ fertilizer, as well as to determine the optimum rate of $N$ and $P$ fertilizer on oil palm aged three years. Research conducted at Block I, IPB-Cargill Jonggol Teaching Farm of Oil Palm, Jonggol, Bogor. This study consisted of two separate experiments are role of nitrogen fertilizer and role of phosphorus fertilizer. The experiment design was randomized block design with one factor as fertillizer rate. Nitrogen fertilizer increased quadratically plant height, length frond, sterm girth, and leaf area on the oil palm aged three years. The optimum rate of $N$ fertilizer on oil palm aged three years was $572 \mathrm{~g} \mathrm{~N}$ plant $^{-1}$ semester ${ }^{-1}$. Phosphorus fertilizer increased quadratically length, girth, and the nutrients levels leaves on the oil palm aged three years. The optimum rate of $\mathrm{P}$ fertilizer was $464 \mathrm{~g}_{2} \mathrm{O}_{5}$ plant $^{-1}$ semester ${ }^{-1}$.
\end{abstract}

Keywords : phisiology, morphology, producty, rate

\section{ABSTRAK}

Pada saat ini lahan semakin terbatas untuk ekstensifikasi dalam perluasan lahan perkebunan kelapa sawit, oleh karena itu perlu adanya peningkatkan produktivitas melalui peningkatkan efektivitas dan efesiensi penggunaan pupuk. Penelitian ini bertujuan untuk mempelajari respon pertumbuhan vegetatif dan produksi terhadap pupuk $N$ dan $P$, serta menentukan dosis optimal pupuk $N$ dan $P$ pada kelapa sawit umur tiga tahun. Penelitian dilaksanakan di blok I, Kebun Pendidikan dan Penelitian Kelapa Sawit Jonggol IPBCargill, Kecamatan Jonggol, Kabupaten Bogor. Penelitian ini terdiri atas dua percobaan terpisah yaitu peran pupuk nitrogen dan peran pupuk fosfor. Rancangan percobaan menggunakan rancangan kelompok lengkap teracak (RKLT) satu faktor yaitu dosis pemupukan. Pupuk nitrogen meningkatkan tinggi tanaman, panjang pelepah, lingkar batang, dan luas daun secara quadratik. Dosis optimum pupuk $N$ pada tanaman kelapa sawit umur tiga tahun adalah $572 \mathrm{~g} \mathrm{~N}$ tanaman $^{-1}$ semester ${ }^{-1}$. Pupuk fosfor meningkatkan panjang pelepah, lingkar batang, dan kadar unsur hara P pada daun ke-17 secara quadratik. Dosis optimum pupuk $P$ pada tanaman kelapa sawit umur tiga tahun adalah $464 \mathrm{~g}_{2} \mathrm{O}_{5}$ tanaman $^{-1}$ semester ${ }^{-1}$.

Kata kunci : dosis, fisiologi, morfologi, produksi 


\section{PENDAHULUAN}

Perkebunan kelapa sawit merupakan salah satu sektor pertanian yang berkembang dengan cepat di Indonesia. Luas lahan perkebunan kelapa sawit di Indonesia pada tahun 2009 seluas 7.95 juta hektar dan pada tahun 2013 meningkat menjadi 10.46 juta hektar. Perkirakan pada tahun 2015 menjadi 11,4 juta hektar. Indonesia menempati posisi pertama sebagai negara produsen minyak kelapa sawit (CPO) terbesar dunia, dengan produksi 27.78 juta ton pada tahun 2013 (BPS, 2015). Kelapa sawit menjadi komoditas perkebunan penghasil devisa tertinggi di bidang pertanian. Komoditas ini menjadi idola bagi petani perkebunan karena minyak nabati yang dihasilkan tinggi dan harganya cukup stabil di pasar.

Lahan semakin terbatas dalam ekstensifikasi perkebunan kelapa sawit, oleh karena itu perlu adanya peningkatkan produksi melalui intensifikasi. Salah satu upaya yang dapat dilakukan adalah dengan meningkatkan produktivitas melalui peningkatan efektivitas dan efesiensi penggunaan pupuk. Efektivitas dan efesiensi pemberian pupuk sangat penting dilakukan karena biaya pemupukan tanaman kelapa sawit sangat besar yaitu 50\%-70\% dari biaya pemeliharaan dan $25 \%$ dari seluruh biaya produksi (Fairhurst et al., 2006). Penambahan unsur hara dapat meningkatkan pertumbuhan tanaman, produksi tanaman, dan kualitas produk yang dihasilkan (PPKS, 2010). Kekurangan salah satu unsur hara akan menyebabkan terhambatnya pertumbuhan vegetatif serta penurunan produksi tanaman kelapa sawit.

Kebutuhan dosis pupuk untuk tanaman kelapa sawit dipengaruhi umur tanaman dan jenis tanah. Pada tanaman kelapa sawit umur tiga tahun dengan jenis tanah mineral dosis pupuk untuk Urea dan SP-36 yaitu $2 \mathrm{~kg}$ dan $1,5 \mathrm{~kg}$ tanaman $^{-1}$ tahun $^{-1}$ (PPKS, 2010). Pemberian dosis pupuk yang tepat akan meningkatkan pertumbuhan vegetatif dan produktivitas tanaman kelapa sawit dan meningkatkan efesiensi biaya produksi.

Unsur nitrogen dan fosfor merupakan dua unsur hara makro utama yang diperlukan untuk pertumbuhan tanaman kelapa sawit. Nitrogen pada tanaman berfungsi pada pembentukan protein, sintesis klorofil dan proses metabolisme. Nitrogen menyusun senyawa organik penting misalnya asam amino, protein dan asam nukleat (Goh dan Hardter, 2010). Munawar (2011) menyatakan bahwa fosfor merupakan komponen struktural dari sejumlah senyawa molekul pentransfer energi ADP, ATP, NAD, NADH, serta senyawa sistem informasi genetik DNA dan
RNA. Unsur P merupakan bagian penting dalam proses fotosintesis dan metabolisme karbohidrat sebagai fungsi regulator pembagian hasil fotosintesis antara sumber dan organ reproduksi, pembentukan inti sel, pembelahan dan perbanyakan sel, pembentukan lemak dan albumin, organisasi sel, dan pengalihan sifat-sifat keturunan.

Penelitian ini bertujuan untuk mempelajari respon pertumbuhan vegetatif dan produksi kelapa sawit umur tiga tahun terhadap pupuk $\mathrm{N}$ dan $\mathrm{P}$ serta menentukan dosis optimal pupuk $\mathrm{N}$ dan $\mathrm{P}$ pada tanaman kelapa sawit belum menghasilkan umur tiga tahun (TBM-3).

\section{METODE PENELITIAN}

Penelitian dilaksanakan di blok I, Kebun Pendidikan dan Penelitian Kelapa Sawit Jonggol IPB-Cargill, Kecamatan Jonggol, Kabupaten Bogor. Lokasi terletak pada ketinggian $209 \mathrm{~m}$ dpl. Analisis jaringan daun dan analisis tanah dilaksanakan di laboratorium Departemen Ilmu Tanah dan Sumber Daya Lahan, IPB. Penelitian dilaksanakan pada bulan Oktober 2015 sampai dengan bulan Maret 2016. Bahan yang digunakan pada penelitian ini adalah tanaman kelapa sawit varietas Damimas umur 30 bulan setelah tanam (BST) yang telah ditanam pada tahun 2013, pupuk Urea $(45 \% \mathrm{~N}), \mathrm{SP}-36\left(36 \% \mathrm{P}_{2} \mathrm{O}_{5}\right), \mathrm{KCL}(60 \%$ $\mathrm{K}_{2} \mathrm{O}$ ) dan kapur pertanian. Alat yang digunakan terdiri atas neraca digital, oven, meteran dan chlorophyll meter SPAD-502.

Penelitian dilakukan dengan dua percobaan yang terpisah, yaitu peranan dosis pupuk nitrogen dan peranan dosis pupuk fosfor. Pemupukan terdiri atas Urea dan SP-36. Rekomendasi dosis pemupukan Urea dan SP-36 optimum tanaman kelapa sawit tanaman belum menghasilkan umur dua tahun (TBM-2) yang ditanam di daerah Jonggol adalah $2 \mathrm{~kg}$ Urea $\operatorname{tanaman}^{-1} \operatorname{tahun}^{-1}$ dan $2 \mathrm{~kg} \mathrm{SP}-36$ tanaman $^{-1}$ tahun $^{-}$ 1 (Faustina 2015). Perlakuan percobaan dosis pemupukan nitrogen dan fosfor yang digunakan berdasarkan dari rekomendasi penelitian sebelumnya.

Percobaan pertama, peranan pupuk nitrogen yang dilakukan dengan menggunakan rancangan kelompok lengkap teracak (RKLT) satu faktor yaitu dosis pemupukan Urea dengan lima taraf perlakuan yaitu, 1) tanpa Urea (N0) sebagai kontrol; 2) $0,5 \mathrm{~kg}$ Urea $\operatorname{tanaman}^{-1}$ semester $^{-1}(\mathrm{~N} 1)$; 3) $1 \mathrm{~kg}$ Urea tanaman ${ }^{-1}$ semester $^{-1}$ (N2); 4) $1,5 \mathrm{~kg}$ Urea tanaman ${ }^{-1}$ semester $^{-1}$ (N3); dan 5) $2 \mathrm{~kg}$ Urea tanaman ${ }^{-1}$ semester $^{-1}$ (N4). Percobaan kedua, peranan pupuk fosfor yang dilakukan dengan menggunakan RKLT satu 
faktor yaitu dosis pemupukan SP-36 dengan empat taraf perlakuan yaitu, 1) tanpa SP-36 (P0) sebagai kontrol; 2) $0,5 \mathrm{~kg} \mathrm{SP}-36 \operatorname{tanaman}^{-1}(\mathrm{P} 1)$; 3) $1 \mathrm{~kg}$ SP-36 $\operatorname{tanaman}^{-1}$ (P2); 4) $1,5 \mathrm{~kg}$ SP-36 tanaman $^{-1}(\mathrm{P} 3)$; dan 5) $2 \mathrm{~kg}$ SP-36 tanaman $^{-1}$ semester $^{-1}$ (P4). Setiap perlakuan terdiri atas 3 ulangan sehingga terdapat 15 satuan percobaan, setiap satuan percobaan terdiri atas 5 tanaman dan setiap tanaman digunakan sebagai sampel.

Penelitian merupakan bagian lanjutan dari penelitian berjudul Optimasi Pupuk Nitrogen dan Fosfor pada Kelapa Sawit Belum Menghasilkan Umur Dua Tahun. Perlakuan dilaksanakan pada bulan November 2015 (32 BST) dan pengamatan dimulai pada bulan November 2015 (32 BST) sampai dengan bulan Maret 2016 (36 BST). Berdasarkan hasil rekomendasi sebelumnya maka pada tanaman kelapa sawit umur tiga tahun ditetapkan dosis pemupukan nitrogen dan fosfor dalam satu tahun, $1 / 2$ dari dosis rekomendasi; sesuai dosis rekomendasi; $1 \frac{1 / 2}{2}$ dari dosis rekomendasi; dan 2 kali dari dosis rekomendasi.

Percobaan pemupukan $\mathrm{N}$ dan $\mathrm{P}$ dilakukan pada $32 \mathrm{BST}$, pemupukan menggunakan setengah dosis dari total pupuk yang diberikan dalam satu tahun untuk setiap perlakuannya. Pemupukan telah dilaksanakan pada bulan November 2015. Pada pemupukan unsur $\mathrm{N}$ menggunakan $0,5 \mathrm{~kg}$ Urea $(46 \% \mathrm{~N}) \operatorname{tanaman}^{-1}$ semester $^{-1}, 1 \mathrm{~kg}$ Urea tanaman $^{-1}$ semester $^{-1}, \quad 1,5 \mathrm{~kg}$ Urea tanaman ${ }^{-1}$ semester $^{-1}$, dan $2 \mathrm{~kg}$ Urea tanaman ${ }^{-1}$ semester $^{-1}$. Pemupukan unsur P menggunakan 0,5 kg SP-36 $\left(\begin{array}{lll}36 \% & \mathrm{P}_{2} \mathrm{O}_{5}\end{array}\right)$ tanaman $^{-1}$ semester $^{-1}, 1 \mathrm{~kg}$ SP-36 tanaman $^{-1}$ semester $^{-1}, 1,5 \mathrm{~kg}$ SP-36 tanaman $^{-1}$ semester $^{-1}$, dan $2 \mathrm{~kg}$ SP-36 tanaman $^{-1}$ semester $^{-1}$. Aplikasi pemupukan Urea dan SP-36 di dalam alur pada radius $1 \mathrm{~m}$ dari pangkal batang tanaman pada piringan.

Pemeliharaan piringan merupakan kegiatan pengendalian gulma di sekitar pangkal batang tanaman membentuk lingkaran. Piringan dipelihara dengan diameter berukuran $2 \mathrm{~m}$ dari tanaman dengan mengendalikan gulma dan tumbuhan selain tanaman pokok. Pengendalian gulma di piringan dilakukan menggunakan herbisida berbahan aktif isopropil amina glifosat. Aplikasi herbisida dilakukan sebelum pemupukan sebanyak satu kali dalam satu semester.

Pengamatan tanggap morfologi tanaman meliputi 8 peubah yaitu: (1) tinggi tanaman; (2) diameter pangkal batang; (3) jumlah pelepah; (4) panjang pelepah daun (rachis) ke-17; (5) panjang anak daun ke-17; (6) lebar anak daun; (7) jumlah anak daun ke-17 dan (8) luas daun ke-17 $\left(\mathrm{m}^{2}\right)$. Pengamatan fisiologi terdiri atas 2 parameter yaitu tingkat kehijauan dan analisis jaringan daun. Tingkat kehijauan daun diukur menggunakan alat
SPAD-502. Analisis jaringan daun dilakukan satu kali pada akhir penelitian dengan mengambil anak daun pelepah ke-17 seluruh tanaman. Anak daun dibersihkan, dipisahkan dari tulang daunnya, dan dioven sebelum dianalisis kandungan haranya. Pengamatan produksi yaitu menghitung jumlah dan berat tandan buah kelapa sawit setiap tanaman.

Analisis tanah dilakukan sebanyak dua kali. Analisis tanah awal dilakukan sebelum pemupukan dengan mengambil contoh tanah sedalam $20 \mathrm{~cm}$ di gawangan sebanyak tiga titik pada setiap ulangan secara acak, sehingga total jumlah titik sampel sebanyak sembilan titik sampel. Sampel tanah dikompositkan semuanya kemudian dianalisis. Sampel tanah dianalisis sifat fisik dan kimianya. Sifat kimia tanah meliputi : $\mathrm{pH}(\mathrm{H} 2 \mathrm{O}$ dan $\mathrm{HCl})$, Kadar C-organik (Walkley $\&$ Black), N-total (Kjeldahl,), P ( $\mathrm{HCl} 25 \%$ dan Bray 1), Kapasitas Tukar Kation, Kejenuhan Basa, Al-dd, dan H-dd. Analisis kandungan hara tanah akhir dilakukan dengan mengambil contoh tanah dalam piringan tanaman pada 36 BST dengan metode komposit pada perlakuan dan ulangan. Sampel tanah diambil di dalam piringan pada kedalaman $0-20 \mathrm{~cm}, 20-40 \mathrm{~cm}$ dan $40-60 \mathrm{~cm}$ di bawah permukaan piringan. Analisis meliputi total unsur hara makro $\mathrm{N}$ dan $\mathrm{P}$. Contoh tanah dikering udarakan, dihaluskan, dan diayak menggunakan saringan. Contoh tanah kemudian dianalisis di laboratorium Departemen Ilmu Tanah dan Sumber Daya Lahan, IPB.

\section{HASIL DAN PEMBAHASAN}

\section{Kondisi Umum}

Penyerapan pupuk yang optimal oleh tanaman bergantung pada ketersediaan air dalam tanah. Pada percobaan ini pemupukan dilakukan pada bulan November ketika curah hujan mencapai $381 \mathrm{~mm}$. Kondisi ini memungkinkan pupuk dapat terserap dengan baik oleh tanaman. Rata-rata curah hujan di lahan penelitian yaitu 156 $\mathrm{mm}$ bulan $^{-1}$, tertinggi pada bulan November 2015. Pada bulan November hingga Maret saat curah hujan optimal untuk pertumbuhan tanaman, pemberian pupuk $\mathrm{N}$ dan $\mathrm{P}$ memberikan respon yang baik terhadap parameter tinggi tanaman, lingkar batang dan panjang pelepah. Curah hujan terendah pada bulan Juni dan Juli 2015 masingmasing $4 \mathrm{~mm}$ dan $2 \mathrm{~mm}$. Bulan kering terjadi selama 6 bulan, dari bulan Mei hingga bulan Oktober dengan curah hujan dibawah $50 \mathrm{~mm}$ bulan $^{-1}$. Hal tersebut menyebabkan pemberian pupuk $\mathrm{N}$ dan $\mathrm{P}$ tidak memberikan respon yang baik terhadap produksi buah kelapa sawit. Kondisi 
tersebut menjadi faktor pembatas berat pada budidaya kelapa sawit. Jumlah bulan kering lebih dari 3 bulan merupakan faktor pembatas berat pada budidaya kelapa sawit (Sugiyono, 2003). Jumlah curah hujan saat bulan April 2015 hingga Maret 2006 pada lahan penelitian di jonggol yaitu $1.875 \mathrm{~mm}$ tahun $^{-1}$. Jumlah curah hujan optimal pada tanaman kelapa sawit yaitu 2.000-2.500 mm tahun $^{-1}$ (Koedadiri, 2003).

Peranan Pupuk Nitrogen Terhadap Tanaman Kelapa Sawit TBM-3
Pemberian pupuk nitrogen pada kelapa sawit TBM-3 pada 36 BST berpengaruh nyata terhadap tinggi tanaman dan luas daun, dan sangat nyata pada lingkar batang dan panjang pelepah. Pemberian unsur $\mathrm{N}$ berpengaruh nyata terhadap tinggi tanaman, lingkar batang dan panjang pelepah pada 34 BST. Hasil produksi pada jumlah janjang, bobot janjang dan bobot rata-rata janjang tidak berpengaruh nyata terhadap pemberian pupuk nitrogen pada umur 34 BST. Rekapitulasi uji $\mathrm{F}$ pengaruh pupuk nitrogen terhadap peubah morfologi, fisiologi dan produksi tanaman kelapa sawit TBM-3 dapat dilihat pada Tabel 1.

Tabel 1. Rekapitulasi hasil uji F pengaruh pupuk nitrogen terhadap peubah morfologi, fisiologi dan produksi pada tanaman kelapa sawit TBM-3

\begin{tabular}{|c|c|c|c|c|c|c|c|c|c|c|}
\hline \multirow{3}{*}{$\begin{array}{l}\text { Waktu pengamatan } \\
\text { (BST) }\end{array}$} & \multicolumn{10}{|c|}{ Respon perlakuan pupuk nitrogen } \\
\hline & \multicolumn{5}{|c|}{ Morfologi } & \multicolumn{2}{|c|}{ Fisiologi } & \multicolumn{3}{|c|}{ Produksi } \\
\hline & TT & LB & JP & PP & LD & KD & KN & $\mathrm{JJ}$ & $\mathrm{BJ}$ & BJR \\
\hline 32 & $* *$ & $*$ & tn & $* *$ & $\operatorname{tn}$ & - & - & tn & tn & $\operatorname{tn}$ \\
\hline 33 & - & - & - & - & - & - & - & tn & tn & $*$ \\
\hline 34 & $* *$ & $* *$ & tn & $* *$ & $\operatorname{tn}$ & - & - & tn & $\operatorname{tn}$ & tn \\
\hline 35 & - & - & - & - & - & - & - & - & - & - \\
\hline 36 & $*$ & $* *$ & tn & $* *$ & $*$ & tn & tn & - & - & - \\
\hline
\end{tabular}

Keterangan: *: nyata pada $\alpha: 5 \%$; *: nyata pada $\alpha: 1 \%$; tn: tidak nyata pada $\alpha: 5 \%$; - : tidak diamati; BST: bulan setelah tanam; TT: tinggi tanaman; JP: jumlah pelepah; LB: lingkar batang; PP: panjang pelepah ke-17; LD: luas daun pelepah ke-17; $\mathrm{KD}$ : kehijauan daun; KN: kadar hara $\mathrm{N}$ daun; JJ: jumlah janjang; $\mathrm{BJ}$ : bobot janjang; BJR: bobot janjang rata-rata

Tanggap Morfologi Tanaman. Pemberian pupuk nitrogen terhadap tinggi tanaman memberikan respon nyata kuadratik pada 36 BST, dan memberikan respon sangat nyata kuadratik pada 32 BST dan 34 BST. Jika dibandingkan dengan kontrol, tinggi tanaman meningkat $8.3 \%$ pada perlakuan dosis $450 \mathrm{~g} \mathrm{~N}_{\text {tanaman }}{ }^{-1}$ semester ${ }^{1}$. Pada lingkar batang memberikan respon sangat nyata kuadratik pada 34 dan $36 \mathrm{BST}$, dan respon nyata kuadratik pada 32 BST. Lingkar batang meningkat $13.04 \%$ dibanding kontrol pada perlakuan $675 \mathrm{~g} \mathrm{~N}$ tanaman $^{-1}$ semester $^{-1}$ pada 36 BST. Pemberian pupuk $\mathrm{N}$ berpengaruh sangat nyata terhadap parameter lingkar batang saat pembibitan utama (Sudradjat et al., 2014). Pemberian pupuk $\mathrm{N}$ terhadap panjang pelepah memberikan respon sangat nyata kuadradtik pada umur 32, 34 dan 36 BST. Panjang pelepah meningkat $8.73 \%$ dibanding kontrol pada perlakuan $225 \mathrm{~g} \mathrm{~N}$ tanaman $^{-1}$ semester $^{-1}$. Pupuk N memberikan respon nyata kuadratik terhadap luas daun pada 36 BST. Luas daun meningkat $13.6 \%$ dibanding dengan kontrol pada perlakuan $675 \mathrm{~g} \mathrm{~N}$ $\operatorname{tanaman}^{-1}$ semester $^{-1}$. Nitrogen berperan dalam proses fotosintesis yang menghasilkan asimilat yang dibutuhkan tanaman saat fase pertumbuhan morfologi (Suharno et all., 2007).

Tanggap Fisiologi Tanaman. Percobaan pupuk nitrogen tidak memberikan perbedaan yang signifikan pada tingkat kehijauan daun pada setiap taraf perlakuan. Semakin hijau warna daun menunjukkan bahwa klorofil yang terkandung semakin tinggi. Pemberian pupuk $\mathrm{N}$ terhadap kadar hara nitrogen pada daun pelepah ke-17 tidak berpengaruh nyata saat 36 BST. Kadar hara N daun pada pemberian berbagai dosis pupuk Urea yaitu sekitar 2.03-2.16\%. Hasil ini lebih rendah dibandingkan kadar hara $\mathrm{N}$ yang optimum pada pelepah daun ke-17 tanaman kelapa sawit. Von Uexküll dan Fairhurst (1991) mengatakan bahwa kadar hara $\mathrm{N}$ optimum pada daun pelepah ke-17 tanaman kelapa sawit kurang dari enam tahun setelah pindah tanam adalah sekitar 2.6-2.9\% dengan batas kritis $2.5 \%$.

Kandungan Hara Tanah. Dinamika hara adalah pergerakan suatu hara pada lapisan tanah dengan kedalaman tertentu. Pengamatan dinamika hara dilakukan dengan mengambil sampel tanah dengan tiga kedalaman $0-20 \mathrm{~cm}, 20-40 \mathrm{~cm}$, dan $40-60 \mathrm{~cm}$ yang diambil dari perlakuan yang memberikan respon terbaik $\left(675 \mathrm{~g} \mathrm{~N}^{-1 a n a m a n}{ }^{-1}\right.$ semester $\left.^{-1}\right)$ dan kontrol $\left(0 \mathrm{~g} \mathrm{~N}\right.$ tanaman $^{-1}$ semester $^{-}$ $\left.{ }^{1}\right)$ pada akhir pengamatan (36 BST). Pada kedalaman 0-20 cm, kadar $\mathrm{N}$ perlakuan $675 \mathrm{~g} \mathrm{~N}$ $\operatorname{tanaman}^{-1}$ semester $^{-1}$ sebesar $0.21 \%$, lebih tinggi dibandingkan kontrol sebesar $0.19 \%$. Pemberian pupuk $\mathrm{N}$ meningkatkan kadar hara $\mathrm{N}$ dalam tanah dibandingkan perlakuan yang tidak diberikan 
pupuk N. Kadar hara menurun pada kedalaman 20-60 cm pada perlakuan $675 \mathrm{~g} \mathrm{tanaman}^{-1}$ semester $^{-1}$, hal ini mungkin terjadi karena ada penyerapan unsur hara dalam tanah pada kedalaman tersebut. Jumlah akar terbanyak ditemukan pada kedalaman tanah 20-60 cm dan absorpsi hara sering terjadi pada lapisan tersebut (Tailliez, 1971). Pergerakan hara $\mathrm{N}$ tersedia dalam tanah dapat dilihat pada Tabel 2.

Tabel 2. Kadar hara Nitrogen dalam tanah pada tanaman kelapa sawit TBM-3 saat umur 36 BST

\begin{tabular}{lcc}
\hline \multirow{2}{*}{$\begin{array}{l}\text { Kedalaman } \\
\text { tanah }(\mathrm{cm})\end{array}$} & \multicolumn{2}{c}{ Kadar N $(\%)$} \\
\cline { 2 - 3 } & $\begin{array}{c}0 \mathrm{~g} \mathrm{~N} \\
\operatorname{tanaman}^{-1} \\
\text { semester }^{-1}\end{array}$ & $\begin{array}{c}675 \mathrm{~g} \mathrm{~N}^{-1} \\
\operatorname{tanaman}^{-1} \\
\text { semester }^{-1}\end{array}$ \\
\hline $0-20$ & 0.19 & 0.21 \\
$20-40$ & 0.17 & 0.17 \\
$40-60$ & 0.14 & 0.17 \\
\hline
\end{tabular}

Penentuan Dosis Optimum Pupuk Nitrogen. Penentuan optimasi dosis pupuk nitrogen didasarkan pada parameter tinggi, lingkar batang dan panjang pelepah yang memberikan hasil cukup signifikan hingga 36 BST. Hal ini berguna untuk menentukan besar dosis pemupukan selanjutnya. Berdasarkan perhitungan persamaan regresi diperoleh hasil dosis optimum pupuk nitrogen sebesar $572 \mathrm{~g} \mathrm{~N}$ tanaman $^{-1}$ semester $^{-1}$, sehingga dosis nitrogen untuk satu tahun yaitu $1144 \mathrm{~g} \mathrm{~N}$ tanaman $^{-1}$ tahun $^{-1}$. Hasil ini lebih besar dari hasil optimasi pada TBM-2 dimana dosis optimum sebesar $879 \mathrm{~g} \mathrm{~N}$ tanaman $^{-1}$ tahun $^{-1}$ (Faustina, 2015). Hal ini membuktikan bahwa penambahan umur tanaman meningkatkan jumlah unsur hara yang dibutuhkan oleh tanaman. Persamaan regresi dosis optimum pupuk nitrogen pada tanaman kelapa sawit TBM-3 dapat dilihat pada Tabel 3.

Tabel 3. Persamaan regresi dosis optimum pupuk nitrogen pada kelapa sawit TBM-3

\begin{tabular}{lcccc}
\hline Peubah & $\begin{array}{c}\text { Umur } \\
(\mathrm{BST})\end{array}$ & Persamaan regresi & $\mathrm{R}^{2}$ & $\begin{array}{c}\text { Dosis optimum } \\
\left(\mathrm{g} N \operatorname{tanaman}^{-1} \text { semester }^{-1}\right)\end{array}$ \\
\hline \multirow{2}{*}{ Tinggi } & 32 & $\mathrm{y}=-0.00006 \mathrm{x}^{2}+0.144 \mathrm{x}+566.9$ & 0.812 & 600 \\
tanaman & 34 & $\mathrm{y}=-0.00006 \mathrm{x}^{2}+0.122 \mathrm{x}+596.7$ & 0.795 & 509 \\
& 36 & $\mathrm{y}=-0.00005 \mathrm{x}^{2}+0.089 \mathrm{x}+629.3$ & 0.759 & 445 \\
\hline \multirow{2}{*}{ Lingkar } & 32 & $\mathrm{y}=-0.00002 \mathrm{x}^{2}+0.051 \mathrm{x}+231.2$ & 0.794 & 725 \\
batang & 34 & $\mathrm{y}=-0.00002 \mathrm{x}^{2}+0.058 \mathrm{x}+235.1$ & 0.946 & 638 \\
\hline \multirow{2}{*}{ Panjang } & 36 & $\mathrm{y}=-0.00002 \mathrm{x}^{2}+0.051 \mathrm{x}+244.8$ & 0.871 & 582 \\
pelepah & 32 & $\mathrm{y}=-0.00004 \mathrm{x}^{2}+0.093 \mathrm{x}+398.6$ & 0.764 & 525 \\
& 34 & $\mathrm{y}=-0.00004 \mathrm{x}^{2}+0.084 \mathrm{x}+416.1$ & 0.787 & 494 \\
\hline
\end{tabular}

Peranan Pupuk Fosfor Terhadap Tanaman Kelapa Sawit TBM-3

Pemberian pupuk fosfor pada tanaman kelapa sawit TBM-3 pada waktu 36 BST memberikan hasil yang berpengaruh sangat nyata terhadap lingkar batang, selain itu pemberian pupuk fosfor juga memberikan hasil yang berpengaruh nyata pada panjang pelepah.

Tabel 4. Rekapitulasi hasil uji F pengaruh pupuk fosfor terhadap peubah morfologi, fisiologi dan produksi pada tanaman kelapa sawit TBM-3

\begin{tabular}{|c|c|c|c|c|c|c|c|c|c|c|}
\hline \multirow{3}{*}{$\begin{array}{l}\text { Waktu } \\
\text { pengamatan } \\
\text { (BST) }\end{array}$} & \multicolumn{10}{|c|}{ Respon perlakuan pupuk fosfor } \\
\hline & \multicolumn{5}{|c|}{ Morfologi } & \multicolumn{2}{|c|}{ Fisiologi } & \multicolumn{3}{|c|}{ Produksi } \\
\hline & TT & LB & JP & $\mathrm{PP}$ & LD & KD & KP & $\mathrm{JJ}$ & $\mathrm{BJ}$ & BJR \\
\hline 32 & $* *$ & $* *$ & $* *$ & $* *$ & $\operatorname{tn}$ & - & - & tn & tn & $\operatorname{tn}$ \\
\hline 33 & - & - & - & - & - & - & - & tn & tn & tn \\
\hline 34 & $*$ & $* *$ & tn & $*$ & tn & - & - & tn & tn & tn \\
\hline 35 & - & - & - & - & - & - & - & - & - & - \\
\hline 36 & tn & $* *$ & tn & $*$ & $\operatorname{tn}$ & tn & $* *$ & - & - & - \\
\hline
\end{tabular}

Keterangan: *: nyata pada $\alpha: 5 \%$; **: nyata pada $\alpha: 1 \%$; tn: tidak nyata pada $\alpha: 5 \%$; - : tidak diamati; BST: bulan setelah tanam; TT: tinggi tanaman; JP: jumlah pelepah; LB: lingkar batang; PP: panjang pelepah ke-17; LD: luas daun pelepah ke-17; KD: kehijauan daun; KP: kadar hara P daun; JJ: jumlah janjang; BJ: bobot janjang; BJR: bobot janjang rata-rata 
Pada 32 BST pemberian fosfor berpengaruh sangat nyata terhadap tinggi tanaman, lingkar batang, jumlah pelepah dan panjang pelepah. Pemberian fosfor terhadap kadar hara $\mathrm{P}$ daun berpengaruh sangat nyata saat umur 36 BST. Rekapitulasi uji F pengaruh pupuk fosfor terhadap peubah morfologi, fisiologi dan produksi tanaman kelapa sawit TBM-3 dapat dilihat pada Tabel 4.

Tanggap Morfologi Tanaman. Pemberian pupuk fosfor memberikan respon sangat nyata kuadratik pada tinggi tanaman saat 32 BST, dan memberikan respon nyata kuadartik pada 34 BST. Jika dibandingkan kontrol, tinggi tanaman meningkat $10.68 \%$ pada perlakuan $540 \mathrm{~g} \mathrm{P}_{2} \mathrm{O}_{5}$ $\operatorname{tanaman}^{-1}$ semester $^{-1}$ pada $36 \mathrm{BST}$. Pemberian pupuk fosfor memberikan respon nyata kuadratik terhadap pertambahan jumlah pelepah pada 32 BST. Pertambahan jumlah pelepah meningkat $1.62 \%$ dibanding kontrol pada perlakuan dosis pupuk 540 g $_{2} \mathrm{O}_{5} \operatorname{tanaman}^{-1}$ semester $^{-1}$ pada 36 BST. Pemberian berbagai dosis pupuk fosfor memberikan respon sangat nyata kuadratik terhadap lingkar batang pada umur 32 hingga 36 BST. Pada lingkar batang pemberian pupuk fosfor memberikan respon yang baik. Peningkatan lingkar batang sebesar $10.39 \%$ dibanding dengan kontrol pada dosis pupuk $360 \mathrm{~g} \mathrm{P}_{2} \mathrm{O}_{5}$ tanaman $^{-1}$ semester ${ }^{-1}$ pada 36 BST. Pemberian unsur $\mathrm{P}_{2} \mathrm{O}_{5}$ memberikan respon sangat nyata quadratik terhadap panjang pelepah tanaman saat umur 32 BST dan respon nyata quadratik pada 34 dan 36 BST. Panjang pelepah meningkat $9.86 \%$ dibanding kontrol pada perlakuan $540 \mathrm{~g}_{2} \mathrm{P}_{5}$ tanaman $^{-1}$ semester $^{-1}$ pada 36 BST.

Tanggap Fisiologi Tanaman. Pemberian pupuk $\mathrm{P}_{2} \mathrm{O}_{5}$ tidak memberikan perbedaan yang signifikan pada tingkat kehijauan daun pada masing-masing taraf perlakuan. Pemberian dosis pupuk fosfor menunjukan respon sangat nyata kuadratik pada kadar hara $\mathrm{P}_{2} \mathrm{O}_{5}$ pada daun pelepah ke-17 saat 36 BST. Kadar hara $\mathrm{P}$ pada daun terbilang cukup tinggi, pada dosis 180-720 g tanaman $^{-1}$ semester $^{-1}$ dengan konsentrasi yaitu sekitar 0.93-1.06\%. Ochs dan Olivin (1977) mengatakan bahwa kadar hara $\mathrm{P}_{2} \mathrm{O}_{5}$ optimum pada daun pelepah ke-17 tanaman kelapa sawit kurang dari enam tahun setelah pindah tanam adalah sekitar $0.16-0.19 \%$ dengan batas kritis $0.15 \%$.
Kandungan Hara Tanah. Pengamatan dinamika hara dilakukan dengan mengambil sampel tanah dengan tiga kedalaman 0-20 cm, 20$40 \mathrm{~cm}$, dan 40-60 cm yang diambil dari perlakuan yang memberikan respon terbaik $\left(540 \mathrm{~g} \mathrm{P}_{2} \mathrm{O}_{5}\right.$ tanaman $^{-1}$ semester $\left.^{-1}\right)$ dan kontrol $\left(\begin{array}{lll}0 & \mathrm{~g} & \mathrm{P}_{2} \mathrm{O}_{5}\end{array}\right.$ tanaman $^{-1}$ semester $\left.^{-1}\right)$ pada akhir pengamatan (36 BST). Pada kedalaman 0-20 cm, kadar $\mathrm{P}_{2} \mathrm{O}_{5}$

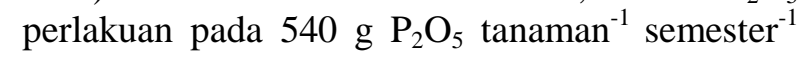
sebesar $16.19 \%$ lebih tinggi dibandingkan kontrol sebesar 12.53\%. Pemberian pupuk $\mathrm{P}_{2} \mathrm{O}_{5}$ meningkatkan kadar $\mathrm{P}_{2} \mathrm{O}_{5}$ dalam tanah dibandingkan perlakuan yang tidak diberikan pupuk $\mathrm{P}_{2} \mathrm{O}_{5}$. Kadar hara menurun pada kedalaman 20-60 cm pada perlakuan $540 \mathrm{~g} \mathrm{P}_{2} \mathrm{O}_{5} \operatorname{tanaman}^{-1}$ semester $^{-1}$, hal ini mungkin terjadi karena ada penyerapan unsur hara dalam tanah pada kedalaman tersebut. Pergerakan hara $\mathrm{P}_{2} \mathrm{O}_{5}$ tersedia dalam tanah dapat dilihat pada Tabel 5 .

Tabel 5. Kadar hara fosfor dalam tanah pada tanaman kelapa sawit TBM-3

\begin{tabular}{lcc}
\hline \multirow{2}{*}{$\begin{array}{l}\text { Kedalaman } \\
\text { tanah }(\mathrm{cm})\end{array}$} & \multicolumn{2}{c}{$\mathrm{Kadar}_{2} \mathrm{O}_{5}(\%)$} \\
\cline { 2 - 3 } & $\begin{array}{c}0 \mathrm{~g} \mathrm{P}_{2} \mathrm{O}_{5} \\
\operatorname{tanaman}^{-1} \\
\text { semester }^{-1}\end{array}$ & $\begin{array}{c}540 \mathrm{~g} \mathrm{P}_{2} \mathrm{O}_{5} \\
\text { tanaman }^{-1} \\
\text { semester }^{-1}\end{array}$ \\
\hline $0-20$ & 12,53 & 16,19 \\
$20-40$ & 12,32 & 12,71 \\
$40-60$ & 14,16 & 14,59 \\
\hline
\end{tabular}

Penentuan Dosis Optimum Pupuk Fosfor. Penentuan optimasi dosis pupuk fosfor didasarkan pada lingkar batang dan panjang pelepah yang memberikan hasil cukup signifikan hingga 36 BST. Berdasarkan perhitungan persamaan regresi diperoleh hasil dosis optimum pupuk kalium sebesar 464 g $_{2} \mathrm{O}_{5}$ tanaman $^{-1}$ semester $^{-1}$ sehingga dosis nitrogen untuk satu tahun yaitu $928 \mathrm{~g} \mathrm{P}_{2} \mathrm{O}_{5}$ tanaman $^{-1}$ tahun $^{-1}$. Hasil ini lebih besar dibandingkan hasil optimasi pada TBM-2 dimana dosis optimum sebesar $604 \mathrm{~g} \mathrm{P}_{2} \mathrm{O}_{5}$ tanaman $^{-1}$ tahun $^{-1}$ (Faustina, 2015). Hal ini membuktikan bahwa penambahan umur tanaman meningkatkan jumlah unsur hara yang dibutuhkan oleh tanaman. Persamaan regresi dosis optimum pupuk fosfor pada tanaman kelapa sawit TBM-3 dapat dilihat pada Tabel 6. 
Tabel 6. Persamaan regresi dosis optimum pupuk fosfor pada kelapa sawit TBM-3

\begin{tabular}{lcccc}
\hline Peubah & $\begin{array}{c}\text { Umur } \\
(\mathrm{BST})\end{array}$ & Persamaan regresi & $\mathrm{R}^{2}$ & $\begin{array}{c}\text { Dosis optimum } \\
\left(\mathrm{g} \mathrm{P}_{2} \mathrm{O}_{5} \text { tanaman }^{-1} \text { semester }^{-1}\right)\end{array}$ \\
\hline \multirow{2}{*}{ Lingkar } & 32 & $\mathrm{y}=-0,00003 \mathrm{x}^{2}+0,059 \mathrm{x}+231,5$ & 0,745 & 492 \\
batang & 34 & $\mathrm{y}=-0,00005 \mathrm{x}^{2}+0,085 \mathrm{x}+237,9$ & 0,764 & 425 \\
& 36 & $\mathrm{y}=-0,00003 \mathrm{x}^{2}+0,051 \mathrm{x}+244,2$ & 0,822 & 425 \\
\hline \multirow{2}{*}{ Panjang } & 32 & $\mathrm{y}=-0,00007 \mathrm{x}^{2}+0,117 \mathrm{x}+395,4$ & 0,865 & 418 \\
pelepah & 34 & $\mathrm{y}=-0,00004 \mathrm{x}^{2}+0,085 \mathrm{x}+411,7$ & 0,962 & 532 \\
& 36 & $\mathrm{y}=-0,00004 \mathrm{x}^{2}+0,079 \mathrm{x}+431,1$ & 0,762 & 494 \\
\hline \multicolumn{5}{c}{ rata-rata } \\
\hline
\end{tabular}

\section{Pembahasan Umum}

Hasil tidak berpengaruh nyata pada sebagian parameter morfologi, fisiologi dan produksi mungkin dikarenakan faktor curah hujan saat bulan kering yang terjadi pada bulan Mei hingga bulan Oktober 2015. Pada bulan tersebut tanaman kelapa sawit mengalami stres defisit air yang mempengaruhi pertumbuhan dan perkembangan tanaman. Faktor curah hujan merupakan salah satu faktor lingkungan yang dapat mempengaruhi pertumbuhan dan perkembangan tanaman kelapa sawit. Faktor jumlah curah hujan sangat penting terhadap pertumbuhan dan perkembangan tanaman kelapa sawit. Pada musim kering penyerapan air terbatas atau terhenti, hal tersebut juga menyebabkan penyerapan unsur $\mathrm{N}$ dan $\mathrm{P}$ terbatas atau terhenti. Kekurangan air mengakibatkan tekanan turgor sel menurun, sehingga tekanan kearah luar dinding sel menjadi menurun. Hal ini mengakibatkan terganggunya pembesaran dan pembelahan sel yang akan menghambat pertumbuhan pada jaringan tanaman (Darmosarkoro et al., 2003). Menurut Voet dan Voet (1995), kekurangan air mempengaruhi penyerapan unsur hara menjadi berkurang, proses fisiologi dan distribusi asimilat terganggu, dan neto fotosintesis menurun.

Percobaan pupuk nitrogen dan fosfor memberikan hasil dosis optimal pada pemupukan tanaman kelapa sawit TBM-3. Dosis yang didapat lebih tinggi dari dosis rekomendasi pada penelitian yang dilakukan pada kelapa sawit TBM-1 dan TBM-2. Perbandingan antara dosis rekomendasi dosis optimum TBM-1 dan dosis optimum TBM-2 dengan dosis optimum kelapa sawit TBM-3 dapat dilihat pada Tabel 7.

Tabel 7. Perbandingan antara dosis rekomendasi dosis optimum TBM-1 dan dosis optimum TBM-2 dengan dosis optimum kelapa sawit TBM-3

\begin{tabular}{|c|c|c|c|}
\hline $\begin{array}{c}\text { Pupuk } \\
\left(\mathrm{g} \text { tanaman }^{-1} \operatorname{tahun}^{-1}\right)\end{array}$ & $\begin{array}{l}\text { Dosis optimum } \\
\text { TBM- }^{\text {a }}\end{array}$ & $\begin{array}{l}\text { Dosis optimum TBM- } \\
2^{\mathrm{b}}\end{array}$ & $\begin{array}{l}\text { Dosis optimum TBM- } \\
3^{\mathrm{c}}\end{array}$ \\
\hline $\mathrm{N}$ & 920 & 879 & 1.144 \\
\hline $\mathrm{P}_{2} \mathrm{O}_{5}$ & 630 & 604 & 928 \\
\hline
\end{tabular}

\section{KESIMPULAN}

Pupuk nitrogen meningkatkan tinggi tanaman, panjang pelepah, lingkar batang, dan luas daun secara quadratik pada kelapa sawit belum menghasilkan umur tiga tahun (TBM-3). Dosis optimum berdasarkan pada tanaman, panjang pelepah, lingkar batang, dan luas daun $572 \mathrm{~g} \mathrm{~N}$ tanaman $^{-1}$ semester $^{-1}$. Pupuk fosfor meningkatkan panjang pelepah, lingkar batang, dan kadar unsur hara $\mathrm{P}$ pada daun ke-17 secara quadratik pada kelapa sawit TBM-3. Dosis optimum berdasarkan pada panjang pelepah dan lingkar batang $464 \mathrm{~g} \mathrm{P}_{2} \mathrm{O}_{5}$ tanaman $^{-1}$ semester $^{-1}$.
Badan Pusat Statistik [BPS]. 2015. Luas Areal Perkebunan Kelapa Sawit. [internet]. [diunduh 2015 Nov 20]. Tersedia pada http://www.bps.go.id.

Darmosarkoro, W., Harahap, I. Y., Syamsudin, E. 2003. Kultur teknis pada tanaman kelapa sawit pada kondisi kekeringan dan upaya penanggulangannya. Hal. 228-243. Dalam W. Darmosarkoro, E. S. Sutarta, dan Winarna $(E d s)$. Lahan dan Pemupukan Kelapa Sawit. Pusat Penelitian Kelapa Sawit, Medan.

\section{DAFTAR PUSTAKA}


Fairhurst, T.H., Caliman, J.P., Hardter, R., Witt, C. 2006. Kelapa sawit: kelainan hara dan pengelolaannya. Potash and Phosphate Institute (PPI), Potash and Phosphate Institute of Canada (PPIC), International Potash Institute (IPI), French Agricultural Research Centre for International Development (CIRAD).

Faustina, E., Sudradjat, Supijatno. 2015. Optimization of Nitrogen and Phosphorus Fertilizer on Two Years Old of Oil Palm (Elaeis guineensis Jacq.). Asian Journal of Applied Sciences. Vol. 03 - Issue 03, June 2015.

Goh, J.K., Hardter, R. 2010. General Oil Palm Nutrition. International Potash Institute Kassel. Germany.

Koedadiri, A. D., Darmosarkoro, W., Sutarta, E. S. 2003. Potensi dan pengelolaan tanah ultisol pada beberapa wilayah perkebunan kelapa sawit di Indonesia. Hal. 1-13. Kultur teknis pada tanaman kelapa sawit pada kondisi kekeringan dan upaya penanggulangannya. Hal. 228-243. Dalam W. Darmosarkoro, E. S. Sutarta, dan Winarna $(E d s)$. Lahan dan Pemupukan Kelapa Sawit. Pusat Penelitian Kelapa Sawit, Medan.

Munawar, A. 2011. Kesuburan Tanah dan Nutrisi Tanaman. Bogor (ID): IPB Press.

Ochs, R., Olivin, J. 1977. Le diagnostic foliaire pour le controle de la nutrition desplantations de palmiers à huile: Prélèvement des échantillions foliares. Oléagineux. 32(5):211-216.

Pusat Penelitian Kelapa Sawit [PKKS]. 2010.

Budidaya Kelapa Sawit. PPKS. Medan.
Shintarika, F., Sudradjat, Supijatno. 2015. Optimasi Dosis Pupuk Nitrogen dan Fosfor pada Tanaman Kelapa Sawit (Elaeis guineensis Jacq.) Belum Menghasilkan Umur Satu Tahun. J. Agron. Indonesia 43 (3) : $250-256$

Sudradjat, Darwis, A., Wachjar, A. 2014. Optimasi dosis pupuk nitrogen dan fosfor pada bibit kelapa sawit (Elaeis guineensis Jacq.) di pembibitan utama. J. Agron. Indonesia. 42 (3) : 222 - 227.

Sugiyono, Harahap, I.Y., Winarna, Koedadiri, A. D., Purba, A., Purba, P. 2003. Penilaian kesesuaian lahan. Hal. (1)2-(1)3. Dalalam: Buana L., Siahaan D. dan Adiputra S. $(E d s)$. Kultur Teknis Kelapa sawit. Pusat Penelitian Kelapa Sawit, Medan.

Suharno, I., Mawardi, Setiabudi, N., Lunga, S., Tjitrosemito. 2007. Efisiensi penggunaan nitrogen pada tipe vegetasi yang bereda di stasiun penelitian taman nasional gunung halimun Jawa Barat. Biodiversitas. 8: 287-294.

Tailliez, B. 1971. The root system of the oil palm on the San Alberto plantation in Colombia. Oleagineux. 26:435-448.

Voet, D., Voet, J. G. 1995. Biochemistry. 2 Ed. New York (US): John Wiley \& Son Inc.

Von Uexküll, H. R., Fairhurst, T. H. 1999. Fertilizing for high yield and quality the oil palm. Dalam: Fairhurst TH dan Mutert E. Interpretation and management of oil palm leaf analysis data. Better Crops International.13:48-51. 